\title{
Identification of signature genes for detecting hedgehog pathway activation in esophageal cancer
}

\author{
Ling Yang ${ }^{1,2, \S}$, Yuehong Bian ${ }^{1, \S}$, Shuhong Huang ${ }^{1}$, Xiaoli Ma1 ${ }^{1}$, Chi Zhang ${ }^{1}$, Xiulan Su ${ }^{2}$, Zi- \\ Jiang Chen ${ }^{3}$, Jingwu Xie ${ }^{4, *}$, and Hongwei Zhang ${ }^{1,{ }^{*}}$ \\ ${ }^{1}$ Institute of Developmental Biology, School of Life Sciences, Shandong University, Jinan, \\ 250100, P.R. China \\ ${ }^{2}$ Clinical Research Center of the Affiliated Hospital, Inner Mongolia Medical College, Hohhot, \\ 010050, P.R. China \\ ${ }^{3}$ Shandong Provincial Key Laboratory of Reproductive Medicine, Reproductive Medical Center, \\ Provincial Hospital Affiliated to Shandong University, Jinan 250021, P.R. China \\ ${ }^{4}$ Wells Center for Pediatric Research, Department of Pediatrics, Division of hematology and \\ Oncology, Indiana University Simon Cancer Center, Indiana University School of Medicine, \\ Indiana 46202, USA
}

\begin{abstract}
The hedgehog signaling pathway plays an important role in cell growth and differentiation both in normal embryonic development and in tumors. Our previous work shows that hedgehog pathway is frequently activated in esophageal cancers. To further elucidate the role of hedgehog pathway in esophageal cancers we examined the expression of the target genes, hedgehog-interacting protein (HIP) and platelet derived growth factor receptor alpha (PDGFR $\alpha$ ) and hedgehog signaling molecules, smoothened (SMO), suppressor of fused $(\mathrm{Su}(\mathrm{Fu}))$ in the specimens using in situ hybridization and RT-PCR. We found that $H I P, P D G F R \alpha, S M O$ and $S u(F u)$ gene highly expressed in the primary esophageal squamous cell carcinomas but not in normal esophageal tissue. The transcripts of HIP, PDGFR $\alpha$ and SMO were expressed in 13 of 15 esophageal cancers. $\mathrm{Su}(\mathrm{Fu})$ expression was missing in 2 esophageal cancers. The results from in-situ hybridization were further confirmed by RT-PCR. Our results revealed a set of genes for detecting hedgehog signaling activation in esophageal cancer.
\end{abstract}

\section{Keywords}

esophageal cancer; hedgehog; hedgehog-interacting protein; platelet derived growth factor receptor alpha; smoothened; suppressor of fused

\section{Introduction}

Hedgehog $(\mathrm{HH})$ signaling pathway regulates many processes in development, homeostasis in tissues, and ectopic expression of $\mathrm{HH}$ signaling pathway components are responsible for tumorigenesis. In the absence of $\mathrm{HH}, \mathrm{PTCH} 1$ prevents SMO from signaling. When $\mathrm{HH}$

Correspondence to Professor Hongwei Zhang, Institute of Developmental Biology, School of Life Sciences, Shandong University, Jinan, 250100, Shandong province, P.R. China. zhw@ @du.edu.cn, jinxie@iupui.edu. Telephone +86-531-88364935 Fax $+86-531-88565610$.

$\S$ These authors contribute equally to this work. 
binds to PTCH1, SMO is free to pass signal to transcriptional factor GLIs and activate the target genes (e.g. PTCH1, GLI1, HIP and PDGFR $\alpha$ ).

Active Smoothened contribute to activating the signaling pathway, result in inappropriate transcription of target genes, which may be important in the pathogenesis of carcinomas. Activated Smoothened mutations have been found in sporadic basal-cell carcinomas [1,2], over expression of smoothened was found in several tumors [3-5]. HIP is the target gene of $\mathrm{HH}$ pathway also is a negative hedgehog signaling regulator by binding to the hedgehog protein. Silence of HIP was found in several cancer cell lines as well as tumors through genetic and/or epigenetic alternations [6-8]. $\mathrm{Su}(\mathrm{Fu})$ is an essential repressor in mammalian hedgehog signaling [9]. Mice with both heterozygous PTCH1 and Su(fu) had higher to develop tumor [10]. Mutations in $\mathrm{Su}(\mathrm{Fu})$ or loss of $\mathrm{Su}(\mathrm{Fu})$ expression was reported in cancer cell lines and tumors [11-14]. Expression of PDGFR $\alpha$ was found in several types of tumors [15-18], and involved in tumor cell growth and metastasis [19-22].

Esophageal cancer is one of the most frequent cancers and with high mortality rates in the world. We have demonstrated the over-expression of Sonic hedgehog $(\mathrm{SHH})$ and its target genes, GLII and PTCHI (patched1) in the tissues of esophageal primary tumors both on mRNA and protein levels. And SMO antagonist or the SHH antibodies treated esophageal cancer cells are inhibited growth and induced apoptosis [23]. But there is short of expression of other genes of this signaling pathway in esophageal primary cancers. To identify if there are activation of other components in this pathway we analyze the expression of $H I P$, $P D G F R \alpha, S M O$ and $S u(F u)$ by using in situ hybridization and RT-PCR.

\section{Material and methods}

\section{Tumor sample}

Specimens from 15 cases of esophageal cancers were received as discarded materials from the Shangdong QiLu Hospital, Jinan, China as our previous report [23]. Pathology reports and $\mathrm{H} \& \mathrm{E}$ staining of each specimen were reviewed to determine the nature of the disease and the tumor histology. Esophageal cancers were identified according to the WHO guideline [24] as squamous cell carcinomas (15 cases) (Table 1). Five specimens of normal esophageal tissues were obtained from five esophageal cancer patients hospitalized in Shandong Provincial Hospital as discarded materials (Table 1).

\section{In situ hybridization}

Tissue sections ( $6 \mu \mathrm{m}$ thick) were mounted onto poly-L-lysine slides. Following deparaffinization, tissue sections were rehydrated in a series of dilutions of ethanol. To enhance signal and facilitate probe penetration, sections were immersed in $0.3 \%$ Triton $\mathrm{X}-100$ solution for $15 \mathrm{~min}$ at room temperature, followed by treatment with proteinase $\mathrm{K}$ (20 $\mu \mathrm{g} / \mathrm{ml})$ for $20 \mathrm{~min}$ at $37^{\circ} \mathrm{C}$. The sections were then incubated with $4 \%(\mathrm{v} / \mathrm{v})$ paraformaldehyde/PBS for 5 min at $4{ }^{\circ} \mathrm{C}$. After washing with PBS and $0.1 \mathrm{M}$ triethanolamine, the slides were incubated with prehybridization solution ( $50 \%$ formamide, $50 \% 4 \times$ standard saline citrate) for $2 \mathrm{hr}$ at $37^{\circ} \mathrm{C}$. The probe was added to each tissue section at a concentration of $1 \mu \mathrm{g} / \mathrm{ml}$ and hybridized overnight at $42^{\circ} \mathrm{C}$. After high-stringency washing $\left(2 \times S S C\right.$ twice, $1 \times S S C$ twice, $0.5 \times \mathrm{SSC}$ twice at $\left.37^{\circ} \mathrm{C}\right)$, sections were incubated with an alkaline phosphatase-conjugated sheep antidigoxigenin antibody, which catalyzed a color reaction with the NBT/BCIP (nitro-blue-tetrazolium/ 5-bromo-4-chloro-3-indolyl phosphate) substrate (Roche). Blue indicated strong hybridization. As negative controls, sense probes were used in all hybridization and no positive signals were observed. 
RT-PCR

Total RNAs were extracted using a RNA extraction kit from Promega according to the manufacturer (Promega, Madison, WI). PCR was performed using 10 pmol each of primers in a standard $50 \mathrm{ml}$ PCR reaction containing $100 \mathrm{mM}$ dNTPs and cDNA from human tissue cDNA expression libraries as template. The primer sequences are shown in (Table 2). DNA was amplified by Taq DNA Polymerase for 30 cycles, and then was run on a $0.8 \%$ agarose gel mixed with ethidium bromide. The bands were visualized under UV light before taking pictures.

\section{Results}

\section{Expression of HIP and PDGFRa in esophageal cancers}

Several putative $\mathrm{HH}$ target genes have been discovered, but only a few of them have been confirmed in esophageal cancer[23]. Several studies indicate that elevated expression of HIP indicates HH signaling activation in human cancer $[11,25]$. PDGFR $\alpha$ expression was elevated in basal cell carcinomas, in which HH pathway was activated[26]. To assess expression of HIP and PDGFR $\alpha$ in esophageal cancers, we examined expression of HIP and PDGFR in 15 cases of esophageal specimens and 5 normal esophageal tissues using in situ hybridization. We found that 13 of the $15(86.7 \%)$ tumor specimens expressed HIP and PDGFR $\alpha$ transcripts (see Table 1 for details). Most of the expression was detected in the tumor tissues (blue in Figure.1a, f, indicated by arrows), not in the stroma (Figure.1a, f, indicated by arrow heads). The anti-sense probe showed good signal (Figure.1a, c, f, h) while the sense probe did not yield any staining (Figure.1b, d, g, i), indicating specificity of in-situ hybridization. Positive staining of HIP and PDGFR $\alpha$ did not show in normal tissue (Figure.1e, j). Further analysis showed that HIP and PDGFR $\alpha$ co-expressed in all the 13 tissues, and there is consistency of expression of PTCH1, Gli1, HIP and PDGFR in 11 of 15 esophageal cancers (Table 1, data obtained from our previous publication[23]), indicating that detection of HIP and PDGFR $\alpha$ is as effective as detection of Gli1 or PTCH1 in esophageal cancer. The result was confirmed by RT-PCR (data not show). Taken together, we found that transcripts of HIP and PDGFR were highly expressed in esophageal cancer specimens which contained activation of hedgehog pathway.

\section{Expression of $\mathrm{SMO}$ and $\mathrm{Su}(\mathrm{Fu})$ in esophageal cancers}

In addition to $\mathrm{HH}$ target genes, we also investigated expression of hedgehog signaling molecules in gastric cancer. We examined expression of $S M O$ in 15 cases and $S u(F u)$ in 11 cases of esophageal specimens and 5 normal esophageal tissues using in situ hybridization. Expressing of $S M O$ was found in 13 of the $15(86.7 \%)$ tumor specimens and $S u(F u)$ was expressed in 7 of the 11 (63.6\%) tumor tissues (see Table 1 for details). Most of the signal (Blue as indicated by arrows in Figure.1k, p) was detected in the tumor tissue, not in the stroma (as indicated by arrow heads in Figure.1k, p). Since the sense probe of $S M O$ and $\mathrm{Su}(\mathrm{Fu})$ did not give any signals, we believe our in-situ hybridization method is very reliable. $S M O$ was co-expressed with HIP and PDGFR $\alpha$ in 13 esophageal cancers. Two cases with expression of $S M O, H I P$ and $P D G F R \alpha$ transcripts lost expression of $S u(F u)$, indicating that silence of $S u(F u)$ may responsible for $\mathrm{HH}$ pathway activating in these two tumors. We did not detect the positive staining of $S M O$ and $S u(F u)$ in normal tissues (Figure.1o, t). We performed RT-PCR to confirm the result of in-situ hybridization (data not show). Taken together, we found elevated expression $\mathrm{SMO}$ and $\mathrm{Su}(\mathrm{Fu})$ in esophageal cancer which contained activation of hedgehog pathway and there were two specimens showed lost expression of $\mathrm{Su}(\mathrm{Fu})$. 


\section{Discussion}

It is important to identify activity of hedgehog pathway in cancers to improve diagnosis and treatment. However, previous studies only detected a few target genes of hedgehog pathway. To better understand expression profile of hedgehog pathway in cancer, we investigate expression of $H I P, P D G F R \alpha, S M O$ and $S u(F u)$ in esophageal cancer. Our result showed that $H I P$ and $P D G F R \alpha$ highly expressed in esophageal cancer, which is consistent with expression of PTCHI and Glil (Table 1). Our results indicate that HIP and PDGFRa is effective as PTCH1 and Gli1 in identification of activation of hedgehog pathway, which is different from the study we perform in gastric cancer [30]. We found that transcripts of $H I P$, $G l i 1$ and $P T C H 1$ are highly expressed in gastric cancer specimens whereas the PDGFR $\alpha$ transcript is detectable only in a subset of cancer with expression of Glil, PTCH1 and HIP. Further more, the study shows that Gli1 can activate PDGFR $\alpha$ in C3H10T1/2 cells[26]. Various expression of PDGFR $\alpha$ in esophageal and gastric cancer suggests that hedgehog pathway functions though different molecule in different type or subtype of cancers. Therefore, identification of mechanism by which PDGFR $\alpha$ is regulated will enrich our understanding in hedgehog-mediate carcinogenesis. Currently, STI571 is used in clinical therapeutics against PDGFR $\alpha$ function[27]. It may shed the light that esophageal cancer with detectable expression of PDGFR $\alpha$ may be eligible for treatment with STI571.

It is reported that transcriptional silencing of HIP protein is found in cancer cell lines and cancer tissues [7]. Our studies did not reveal any reduced expression of HIP in tumors with detectable expression of Glil and PTCH1, suggesting that silencing of HIP in esophageal cancer is not a major mechanism for $\mathrm{HH}$ signaling activation. There are several reports indicating that alterations of $\mathrm{HH}$ signaling molecules may be responsible for Hh signaling activation. $\mathrm{Su}(\mathrm{Fu})$ is an essential repressor in mammalian hedgehog signaling [9], inhibiting the function of GLI molecules through several mechanisms [28]. Mutations in $\mathrm{Su}(\mathrm{Fu}$ ) have been found in cancer cell lines and tumors $[11,13,14]$. However, we did not find significant alteration in the expression of $S u(F u)$ in esophageal cancer, suggesting that $S u(F u)$ inactivation is not very common in esophageal cancer. SMO expression is elevated in a subset of prostate cancer specimens [29]. Our data showed SMO highly expressed in esophageal cancer and expression of $S M O$ was consistent with expression of $H I P$ and PDGFR $\alpha$. Whether the SMO transcript level can be used to detect HH signaling activation in other subtypes of esophageal cancer remains to be determined.

Our study found that $H I P, P D G F R \alpha, S M O$ and $S u(F u)$ gene are highly expressed in the primary esophageal squamous cell carcinomas. The transcripts of HIP, PDGFR $\alpha$ and SMO were expressed in 13 of 15 esophageal cancers. $S u(F u)$ expression was missing in 2 esophageal cancer specimens. The results indicate that activation of the hedgehog pathway occurs frequently in esophageal cancers. Our results revealed a set of genes for detecting $\mathrm{Hh}$ signaling activation in esophageal cancer.

\section{Acknowledgments}

This work was supported by the National Natural Science Foundation of China (30671072 and 30570967) and the Ministry of Science and Technology of China (2007CB947100 and 2007CB815800).

\section{References}

1. Xie J, Murone M, Luoh SM, Ryan A, Gu Q, Zhang C, Bonifas JM, Lam CW, Hynes M, Goddard A, Rosenthal A, Epstein EH Jr, de Sauvage FJ. Activating Smoothened mutations in sporadic basal-cell carcinoma. Nature. 1998; 391:90-2. [PubMed: 9422511] 
2. Lam CW, Xie J, To KF, Ng HK, Lee KC, Yuen NW, Lim PL, Chan LY, Tong SF, McCormick F. A frequent activated smoothened mutation in sporadic basal cell carcinomas. Oncogene. 1999; 18:833-6. [PubMed: 9989836]

3. Kallassy M, Toftgard R, Ueda M, Nakazawa K, Vorechovsky I, Yamasaki H, Nakazawa H. Patched (ptch)-associated preferential expression of smoothened (smoh) in human basal cell carcinoma of the skin. Cancer Res. 1997; 57:4731-5. [PubMed: 9354432]

4. Oniscu A, James RM, Morris RG, Bader S, Malcomson RD, Harrison DJ. Expression of Sonic hedgehog pathway genes is altered in colonic neoplasia. J Pathol. 2004; 203:909-17. [PubMed: 15258993]

5. Shao J, Zhang L, Gao J, Li Z, Chen Z. Aberrant expression of PTCH (patched gene) and Smo (smoothened gene) in human pancreatic cancerous tissues and its association with hyperglycemia. Pancreas. 2006; 33:38-44. [PubMed: 16804411]

6. Martin ST, Sato N, Dhara S, Chang R, Hustinx SR, Abe T, Maitra A, Goggins M. Aberrant methylation of the Human Hedgehog interacting protein (HHIP) gene in pancreatic neoplasms. Cancer Biol Ther. 2005; 4:728-33. [PubMed: 15970691]

7. Taniguchi H, Yamamoto H, Akutsu N, Nosho K, Adachi Y, Imai K, Shinomura Y. Transcriptional silencing of hedgehog-interacting protein by $\mathrm{CpG}$ hypermethylation and chromatic structure in human gastrointestinal cancer. J Pathol. 2007; 213:131-9. [PubMed: 17724792]

8. Tada M, Kanai F, Tanaka Y, Tateishi K, Ohta M, Asaoka Y, Seto M, Muroyama R, Fukai K, Imazeki F, Kawabe T, Yokosuka O, Omata M. Down-regulation of hedgehog-interacting protein through genetic and epigenetic alterations in human hepatocellular carcinoma. Clin Cancer Res. 2008; 14:3768-76. [PubMed: 18559595]

9. Svard J, Heby-Henricson K, Persson-Lek M, Rozell B, Lauth M, Bergstrom A, Ericson J, Toftgard $\mathrm{R}$, Teglund S. Genetic elimination of Suppressor of fused reveals an essential repressor function in the mammalian Hedgehog signaling pathway. Dev Cell. 2006; 10:187-97. [PubMed: 16459298]

10. Svard J, Rozell B, Toftgard R, Teglund S. Tumor suppressor gene co-operativity in compound Patched 1 and suppressor of fused heterozygous mutant mice. Mol Carcinog. 2009; 48:408-19. [PubMed: 18781608]

11. Sheng T, Li C, Zhang X, Chi S, He N, Chen K, McCormick F, Gatalica Z, Xie J. Activation of the hedgehog pathway in advanced prostate cancer. Mol Cancer. 2004; 3:29. [PubMed: 15482598]

12. Chi S, Huang S, Li C, Zhang X, He N, Bhutani MS, Jones D, Castro CY, Logrono R, Haque A, Zwischenberger J, Tyring SK, Zhang H, Xie J. Activation of the hedgehog pathway in a subset of lung cancers. Cancer Lett. 2006; 244:53-60. [PubMed: 16446029]

13. Reifenberger J, Wolter M, Knobbe CB, Kohler B, Schonicke A, Scharwachter C, Kumar K, Blaschke B, Ruzicka T, Reifenberger G. Somatic mutations in the PTCH, SMOH, SUFUH and TP53 genes in sporadic basal cell carcinomas. Br J Dermatol. 2005; 152:43-51. [PubMed: 15656799]

14. Taylor MD, Liu L, Raffel C, Hui CC, Mainprize TG, Zhang X, Agatep R, Chiappa S, Gao L, Lowrance A, Hao A, Goldstein AM, Stavrou T, Scherer SW, Dura WT, Wainwright B, Squire JA, Rutka JT, Hogg D. Mutations in SUFU predispose to medulloblastoma. Nat Genet. 2002; 31:30610. [PubMed: 12068298]

15. Rikova K, Guo A, Zeng Q, Possemato A, Yu J, Haack H, Nardone J, Lee K, Reeves C, Li Y, Hu Y, Tan Z, Stokes M, Sullivan L, Mitchell J, Wetzel R, Macneill J, Ren JM, Yuan J, Bakalarski CE, Villen J, Kornhauser JM, Smith B, Li D, Zhou X, Gygi SP, Gu TL, Polakiewicz RD, Rush J, Comb MJ. Global survey of phosphotyrosine signaling identifies oncogenic kinases in lung cancer. Cell. 2007; 131:1190-203. [PubMed: 18083107]

16. Taja-Chayeb L, Chavez-Blanco A, Martinez-Tlahuel J, Gonzalez-Fierro A, Candelaria M, Chanona-Vilchis J, Robles E, Duenas-Gonzalez A. Expression of platelet derived growth factor family members and the potential role of imatinib mesylate for cervical cancer. Cancer Cell Int. 2006; 6:22. [PubMed: 17014709]

17. Zhang T, Sun HC, Xu Y, Zhang KZ, Wang L, Qin LX, Wu WZ, Liu YK, Ye SL, Tang ZY. Overexpression of platelet-derived growth factor receptor alpha in endothelial cells of hepatocellular carcinoma associated with high metastatic potential. Clin Cancer Res. 2005; 11:8557-63. [PubMed: 16361537] 
18. Matei D, Emerson RE, Lai YC, Baldridge LA, Rao J, Yiannoutsos C, Donner DD. Autocrine activation of PDGFRalpha promotes the progression of ovarian cancer. Oncogene. 2006; 25:20609. [PubMed: 16331269]

19. Jechlinger M, Sommer A, Moriggl R, Seither P, Kraut N, Capodiecci P, Donovan M, CordonCardo C, Beug H, Grunert S. Autocrine PDGFR signaling promotes mammary cancer metastasis. J Clin Invest. 2006; 116:1561-70. [PubMed: 16741576]

20. Lev DC, Kim SJ, Onn A, Stone V, Nam DH, Yazici S, Fidler IJ, Price JE. Inhibition of plateletderived growth factor receptor signaling restricts the growth of human breast cancer in the bone of nude mice. Clin Cancer Res. 2005; 11:306-14. [PubMed: 15671560]

21. Russell MR, Jamieson WL, Dolloff NG, Fatatis A. The alpha-receptor for platelet-derived growth factor as a target for antibody-mediated inhibition of skeletal metastases from prostate cancer cells. Oncogene. 2009; 28:412-21. [PubMed: 18850002]

22. Wehler TC, Frerichs K, Graf C, Drescher D, Schimanski K, Biesterfeld S, Berger MR, Kanzler S, Junginger T, Galle PR, Moehler M, Gockel I, Schimanski CC. PDGFRalpha/beta expression correlates with the metastatic behavior of human colorectal cancer: a possible rationale for a molecular targeting strategy. Oncol Rep. 2008; 19:697-704. [PubMed: 18288404]

23. Ma X, Sheng T, Zhang Y, Zhang X, He J, Huang S, Chen K, Sultz J, Adegboyega PA, Zhang H, Xie J. Hedgehog signaling is activated in subsets of esophageal cancers. Int J Cancer. 2006; 118:139-48. [PubMed: 16003737]

24. Sarbia M, Becker KF, Hofler H. Pathology of upper gastrointestinal malignancies. Semin Oncol. 2004; 31:465-75. [PubMed: 15297939]

25. Bonifas JM, Pennypacker S, Chuang PT, McMahon AP, Williams M, Rosenthal A, De Sauvage FJ, Epstein EH Jr. Activation of expression of hedgehog target genes in basal cell carcinomas. J Invest Dermatol. 2001; 116:739-42. [PubMed: 11348463]

26. Xie J, Aszterbaum M, Zhang X, Bonifas JM, Zachary C, Epstein E, McCormick F. A role of PDGFRalpha in basal cell carcinoma proliferation. Proc Natl Acad Sci U S A. 2001; 98:9255-9. [PubMed: 11481486]

27. Heinrich MC, Corless CL, Demetri GD, Blanke CD, von Mehren M, Joensuu H, McGreevey LS, Chen CJ, Van den Abbeele AD, Druker BJ, Kiese B, Eisenberg B, Roberts PJ, Singer S, Fletcher CD, Silberman S, Dimitrijevic S, Fletcher JA. Kinase mutations and imatinib response in patients with metastatic gastrointestinal stromal tumor. J Clin Oncol. 2003; 21:4342-9. [PubMed: 14645423]

28. Barnfield PC, Zhang X, Thanabalasingham V, Yoshida M, Hui CC. Negative regulation of Gli1 and Gli2 activator function by Suppressor of fused through multiple mechanisms. Differentiation. 2005; 73:397-405. [PubMed: 16316410]

29. Karhadkar SS, Bova GS, Abdallah N, Dhara S, Gardner D, Maitra A, Isaacs JT, Berman DM, Beachy PA. Hedgehog signalling in prostate regeneration, neoplasia and metastasis. Nature. 2004; 431:707-12. [PubMed: 15361885]

30. Yang L, Huang SH, Bian YH, Ma XL, Zhang HW, Xie JW. Indentification of signature genes for detecting hedgehog signaling activation in gastric cancer. Molecular Medicine Reports. 2010; 3:473-478. [PubMed: 21472265] 


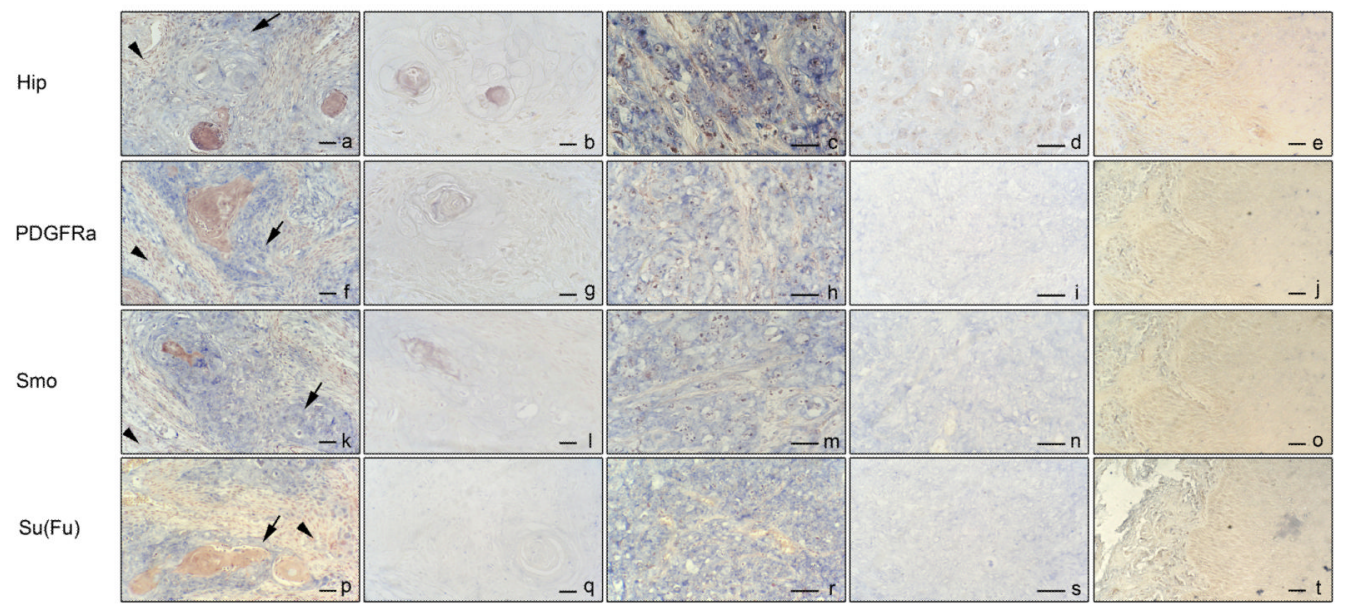

Figure 1.

Expression of HIP, PDGFR $\alpha, S M O$ and $S u(F u)$ in esophageal tumors. HIP, PDGFR , SMO and $S u(F u)$ transcript (blue as positive, indicated by arrows) was detected by in situ hybridization in normal esophageal tissue (e, j, o, t), well-differentiated Squamous Cell Carcinoma (a, f, k, p) and poorly-differentiated Squamous Cell Carcinoma (c, h, m, r), b, d, $\mathrm{g}, \mathrm{i}, 1, \mathrm{n}, \mathrm{q}$ and s are their controls with respective sense probe. Bar presents $200 \mu \mathrm{m}$. 


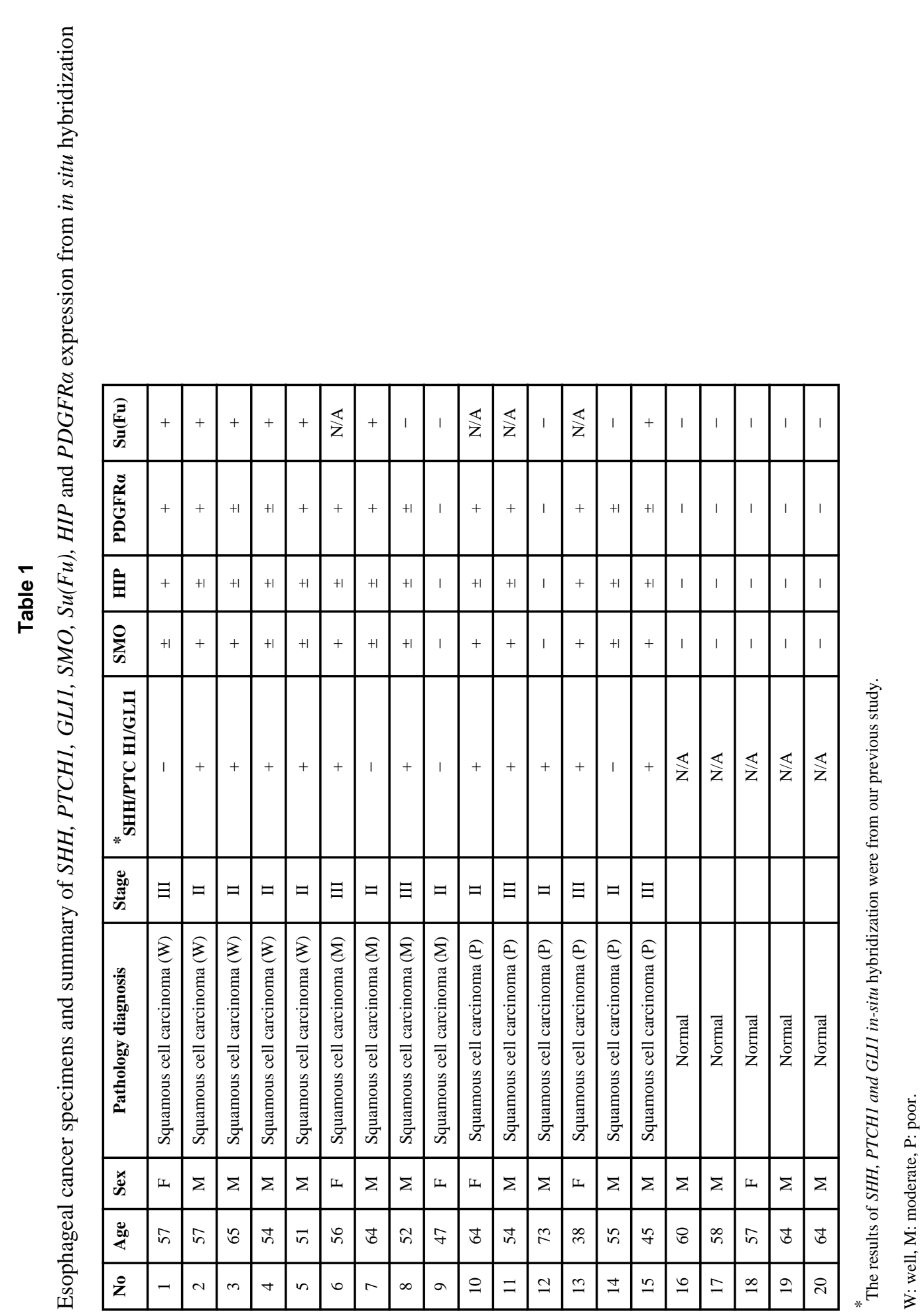

Pathol Oncol Res. Author manuscript; available in PMC 2011 July 15. 
Table 2

Primers used in RT-PCR.

\begin{tabular}{ll}
\hline Gene name & Primers \\
$S M O$ & F: AAGGCCACGCTGCTCATCTGG \\
& R: CATTGAGGTCAAAGGCCAAGC \\
$S u(F u)$ & F: AGAGTGCCGCCGCCTTTACC \\
& R: ACGGGCTGCATCTGTGGGTC \\
$H I P$ & F: TTCCATACCAAGGAGCAACC \\
& R: TCTTGCCACTGCTTTGTCAC \\
$P G D F R \alpha$ & F: GCTTTCATTACCCTCTATCCT \\
& R: GAATCATCCTCCACGA \\
\hline
\end{tabular}

Pathol Oncol Res. Author manuscript; available in PMC 2011 July 15. 